\title{
RISK ANALYSIS RELATED TO QUALITY MANAGEMENT PRINCIPLES
}

\section{David Vykydal, Petra Halfarová, Jaroslav Nenadál, Jiří Plura, Edita Hekelová1}

Department of Quality Management, Faculty of Metallurgy and Material Engineering, VSB -

Technical University of Ostrava, e-mail: david.vykydal@vsb.cz

${ }^{1}$ Faculty of Mechanical Engineering, Slovak University of Technology of Bratislava, e-mail: edita.hekelova@stuba.sk

Keywords: quality management, quality management principles, risk, customer loyalty, benchmarking

\begin{abstract}
Efficient and effective implementation of quality management principles asks for a responsible approach from top managers' perspectives. A study of the current state of affairs in Czech organizations discovers a lot of shortcomings in this field that can be changed to vary managerial risks. The article identifies and analyses some of them and gives short guidance for appropriate treatment. Text of the article reflects the authors' experience as well as knowledge obtained from the systematic analysis of industrial companies' environments.
\end{abstract}

\section{INTRODUCTION}

All activities of any organization involve risks. This fact is valid also for the establishment and development of modern quality management systems. ISO Guide 73 defines risk as the "effect of uncertainty on objectives" [1]. An effect is understood as a deviation from expected or planned state. Such a state is usually described through strategic quality objectives for the quality management system. This guide also notes that uncertainty could be the state of deficiency of information related to the understanding or knowledge of a certain event. We can view risk as the chance of a particular situation or event that will have an impact on organizations' objectives occurring within a stated period of time [2].

Each quality management system must be based on valuable principles. In our opinion, it is important to identify serious risks related to these principles before establishing quality management systems. Therefore, let us briefly recall the fundamental quality management principles according to the ISO 9000 family of standards - see also Annex A [3]:

- Customer focus

- Leadership

- Involvement of people

- $\quad$ Process approach

- $\quad$ Systems approach to management

- Factual approach to decision making

- Continual improvement

- Mutually beneficial supplier relationship.

Short definitions of these principles are included in Table 1. Our experience allowed us to define our input thesis as follows: There are important risks related to quality management principles in Czech organizations. To prove this thesis, we conducted the following activities: 


\section{IDENTIFICATION OF THE MOST SERIOUS RISKS RELATED TO EACH OF THE MENTIONED QUALITY MANAGEMENT PRINCIPLES}

Risk identification is process of finding, recognizing and describing risks. For this purpose, we organized special workshops with 36 very experienced quality managers from different Czech companies. A focus group technique was used to openly discuss individual opinions. Because of the rather subjective nature of this methodology, we held six focus groups (each group involved only six quality managers). Discussions were oriented around the level of risk perception. The result of each focus group was a particular list of risks. Finally, all participants were committed to reach a consensus on to the most serious risks during a special consensus meeting. Fundamental rule was that only one of the identified risks could be added to each of the quality management principles. The results of such a consensus meeting are summed up at the table 1.

Table.1: The most serious risks related to the quality management principles at Czech companies

\begin{tabular}{|c|c|c|}
\hline management & $\begin{array}{l}\text { Definition of the principle } \\
\text { according to [3] }\end{array}$ & The most serious risk \\
\hline Customer focus & $\begin{array}{l}\text { Organizations depend on their } \\
\text { customers and should } \\
\text { therefore understand current } \\
\text { and future customer needs, } \\
\text { meet customer requirements } \\
\text { and strive to exceed customer } \\
\text { expectations. }\end{array}$ & \begin{tabular}{lll} 
Customer & \multicolumn{2}{c}{ loyalty and } \\
customer value are not \\
measured in a systematic \\
manner.
\end{tabular} \\
\hline Leadership & $\begin{array}{l}\text { Leaders establish unity of } \\
\text { purpose and the direction of an } \\
\text { organization. They should } \\
\text { create and maintain an internal } \\
\text { environment in which people } \\
\text { can become fully involved in } \\
\text { achieving the organization's } \\
\text { objectives. }\end{array}$ & $\begin{array}{l}\text { Quality policy and quality } \\
\text { objectives are not derived from } \\
\text { the organizations' mission, } \\
\text { vision and values. }\end{array}$ \\
\hline Involvement of people & $\begin{array}{l}\text { People at all levels are the } \\
\text { essence of an organization and } \\
\text { their full involvement enables } \\
\text { their abilities to be used for the } \\
\text { organization's benefit. }\end{array}$ & $\begin{array}{l}\text { Knowledge sharing is not a } \\
\text { company value. }\end{array}$ \\
\hline Process approach & $\begin{array}{l}\text { A desired result is achieved } \\
\text { more efficiently when } \\
\text { activities and related resources } \\
\text { are managed as a process. }\end{array}$ & $\begin{array}{l}\text { An incorrect process } \\
\text { performance measurement } \\
\text { methodology is used. }\end{array}$ \\
\hline $\begin{array}{l}\text { Systems approach to } \\
\text { management }\end{array}$ & $\begin{array}{l}\text { Identifying, understanding and } \\
\text { managing interrelated } \\
\text { processes as a system } \\
\text { contributes to the } \\
\text { organization's effectiveness } \\
\text { and efficiency in achieving its }\end{array}$ & $\begin{array}{l}\text { Interrelations among processes } \\
\text { are not described and } \\
\text { understood. }\end{array}$ \\
\hline
\end{tabular}




\begin{tabular}{|l|l|l|}
\hline $\begin{array}{l}\text { Factual approach to decision } \\
\text { making }\end{array}$ & $\begin{array}{l}\text { objectives. } \\
\text { offective decisions are based } \\
\text { information. }\end{array}$ & $\begin{array}{l}\text { Reviews of the leading } \\
\text { organizations' performance is } \\
\text { not done systematically. }\end{array}$ \\
\hline Continual improvement & $\begin{array}{l}\text { Continual improvement of the } \\
\text { organization's overall } \\
\text { performance should be a a } \\
\text { permanent objective of the } \\
\text { organization. }\end{array}$ & $\begin{array}{l}\text { Corrective actions take priority } \\
\text { over product or process } \\
\text { innovations. }\end{array}$ \\
\hline $\begin{array}{l}\text { Mutually beneficial supplier } \\
\text { relationship }\end{array}$ & $\begin{array}{l}\text { An organization and its } \\
\text { suppliers are interdependent } \\
\text { and a mutually beneficial } \\
\text { relationship enhances the } \\
\text { ability of both to create value. }\end{array}$ & $\begin{array}{l}\text { Partnership with suppliers is } \\
\text { mostly underestimated. }\end{array}$ \\
\hline
\end{tabular}

Source: own work

\section{RISKS ANALYSIS}

Once these risks were discovered, risk analysis and assessment could follow. A simple 3 x 3 qualitative risk matrix (a tool for ranking and displaying risks) was used for such analysis - it was very easy to use and understandable for all participants. Three ranges of likelihood for the occurrence of a certain risk and its consequences - its impact on quality management system performance - were identified. Then each risk from table 1 was analysed and placed into the risk matrix.

\begin{tabular}{|c|c|c|c|}
\hline $\begin{array}{l}\text { Very } \\
\text { likely }\end{array}$ & & $\begin{array}{l}\text { - Reviews of the leading organizations' } \\
\text { performance are not made } \\
\text { systematically. } \\
\text { - Corrective actions take priority over } \\
\text { product or process innovations. }\end{array}$ & $\begin{array}{l}\text { - Customer loyalty and customer } \\
\text { value are not measured in a } \\
\text { systematic manner. } \\
\text { - Partnership with suppliers is } \\
\text { mostly underestimated. }\end{array}$ \\
\hline Likely & & $\begin{array}{l}\text { - Quality policy and quality objectives } \\
\text { are not derived from the organization's } \\
\text { mission, vision and values. }\end{array}$ & $\begin{array}{l}\text { - An incorrect process } \\
\text { performance measurement } \\
\text { methodology is used. } \\
\text { - Knowledge sharing is not a } \\
\text { company value. }\end{array}$ \\
\hline \multirow[t]{2}{*}{ Unlikely } & & $\begin{array}{l}\text { - Interrelations among processes are not } \\
\text { described and understood. }\end{array}$ & \\
\hline & Minor & Moderate & Major \\
\hline
\end{tabular}

Figure 1: Qualitative risk matrix ( L - likelihood of risk occurrence, I-overall impact on quality management system performance ) Source: own work 
The result of the qualitative risk analysis is illustrated in figure 1. It is evident that risks described as "Customer loyalty and customer value are not measured" and "Partnership with suppliers is mostly underestimated” were recognized as the most serious ones. But risks with moderate impact or risk assessed as "likely” from likelihood perspective also ask for relevant treatment.

\section{PROPOSAL FOR THE TREATMENT OF RISKS}

Risk treatment represents a set of various activities aimed at modifying a certain risk. All risks related to quality management principles should be mitigated naturally through suitable preventive actions. Only two of the aforementioned risks will be treated here due to the limited scope of this article:

- customer loyalty and customer value are not measured in a systematic manner and

- reviews of the leading organizations’ performance are not made systematically.

Customer loyalty is about future customer behaviour within a competitive environment; repurchasing and positive recommendations are crucial for the sustained success of any organization. How can risk be treated in the absence of systematic measuring of customer loyalty? We are able to distinguish three basic types of customer loyalty: advocacy, purchasing and retention. Advocacy loyalty reflects the degree to which customers play the role of advocates by way of recommendations, choosing the same product again, etc. Purchasing loyalty reflects the degree to which customers will increase their purchasing behaviour, including purchasing different products from the same company. And finally, retention loyalty reflects the degree to which customers remain with the same company. The following table (Table 2) can serve as a guideline for customer loyalty measurement.

Table 2: Customer loyalty: what can be measured

\begin{tabular}{|l|c|}
\hline Type of customer loyalty & Loyalty index related to loyalty factor: \\
\hline Advocacy loyalty & - Overall satisfaction \\
& - Choosing the product again \\
\hline Purchasing loyalty & - Recommendations \\
\hline Retention loyalty & - Purchase different products \\
& - Purchase more expensive products \\
& - Purchase larger quantities \\
\hline & - Purchase from competitors \\
& - Switch to another supplier \\
\hline
\end{tabular}

Source: own work

It is obvious that the measurement of the last type of customer loyalty (retention) is based on a reverse calculation -for example, higher scores mean a lower likelihood of purchasing from competitors. B. E. Hayes gives nice proposals in this field [4].

But let us pay attention to a second risk - the risk identified as "reviews of the leading organizations performance are not made systematically". The treatment of this risk seems to be simple: we recommend benchmarking as the best approach. We are able to find many various definitions and models of benchmarking. For example, according to EFQM (European Foundation 
for Quality Management), benchmarking is the systematic comparison of approaches with other relevant organizations in order to gain insights that will help the organization to take action to improve its performance [5]. Xerox Co. says that benchmarking is "the continuous process of measuring our products, services, and practices against our toughest competitors or those companies known as leaders" [6]. And finally, the last version of the ISO 9004:2009 recommends in cl. 8.3.5 that the organization should establish and maintain a methodology for benchmarking that defines the basic rules for all steps in such a process [3]. Most benchmarking models consist of four fundamental phases:

$$
\begin{array}{ll}
\text { - } & \text { planning, } \\
\text { - } & \text { analysis, } \\
\text { - } & \text { integration, } \\
\text { - } & \text { action. }
\end{array}
$$

See also [6 - 9]. The problem is that all models assume that the organizations are ready to perform benchmarking studies.

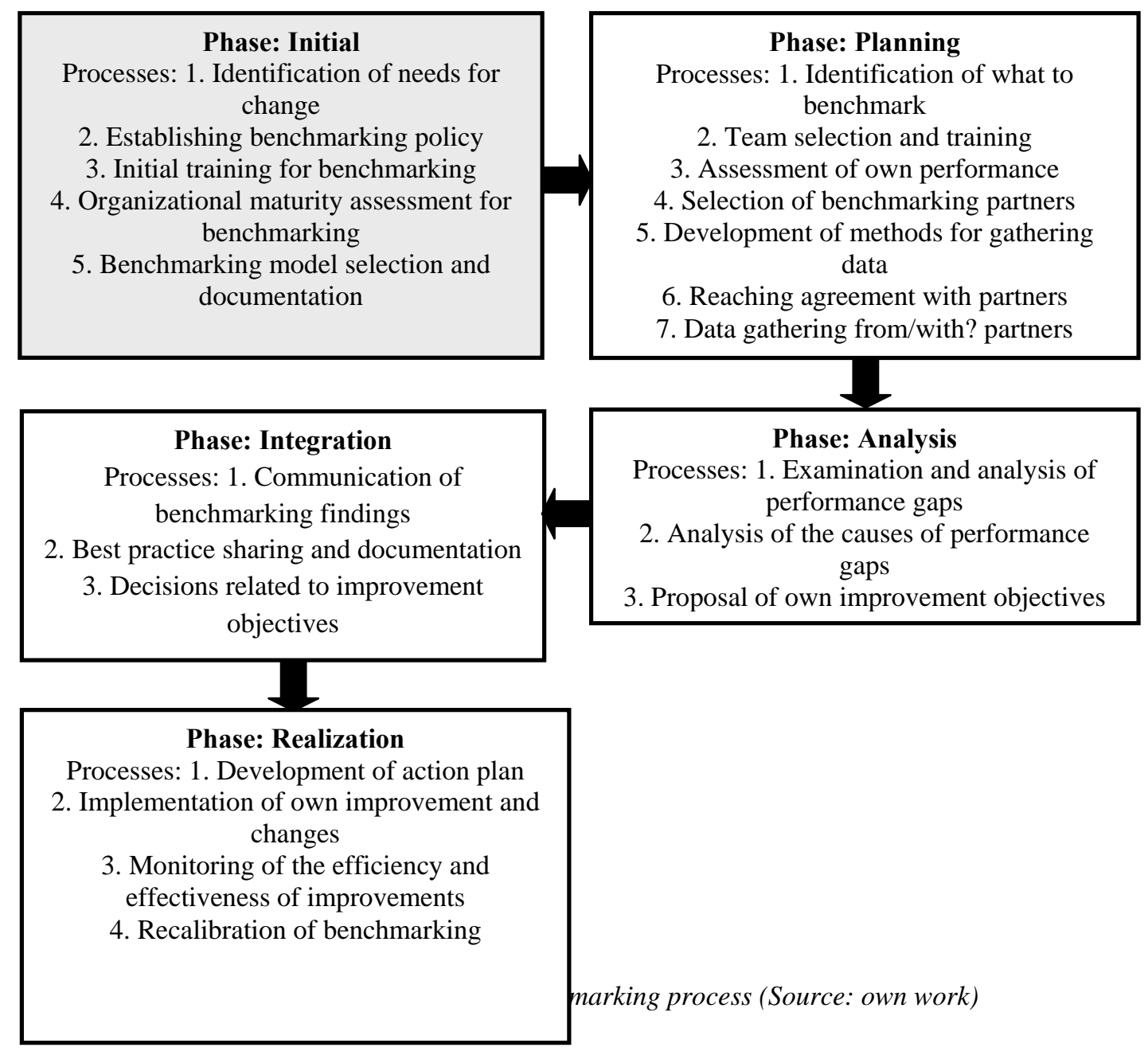


The current situation in Czech organizations is unfortunately rather different! Benchmarking is underestimated, full of misunderstandings, etc. This is why we propose the model of benchmarking presented in fig. 2.

Inclusion of the so-called benchmarking initial phase is quite a new idea. Its main purpose is to create an organizational environment positively oriented to benchmarking activities as well as to prepare people within the organization for proactive participation in various benchmarking projects. The top management role is crucial during this phase!

\section{CONCLUSION}

Each risk can be usually seen from two perspectives:

a) as a danger (downside risk) or

b) as an opportunity (upside risk).

We suppose that this article has already demonstrated that the lack of relevant information on how to implement quality management principles effectively represents a huge danger. But we also tried to show (through our proposals for customer loyalty measurement and benchmarking) that there are many opportunities to eliminate dangers at Czech companies.

This article is granted by special project n. SK-CZ-0138-11 titled "Benchmarking - a strategy for SME”.

\section{REFERENCES}

[1] ISO Guide 73 Risk Management - Vocabulary. Geneve : ISO, 2009

[2] ASBURY,St. - ASHWELL, P.: Health and Safety, Environmental and Quality Audits. A risk based approach. Amsterdam : Elsevier, 2007, 230 p. (ISBN 978-0-750-68026-4)

[3] EN ISO 9004:2009 Managing for the sustained success of an organization - A quality management approach. Geneve : ISO, 2009

[4] HAYES,E., B.: Beyond the Ultimate Question. A Systematic Approach to Improve Customer Loyalty. Milwaukee : ASQ Quality Press. 2010, 396 p. (ISBN 978-0-87389-772-3)

[5] EFQM Excellence Model 2010. Brussels: EFQM. 2009, 32 p. (ISBN 978-90-5236-501-5)

[6] CAMP.R.C.: Business Process Benchmarking. Milwaukee: ASQC Quality Press. 1995, 464 p. (ISBN 0-87389-296-8)

[7] BURKE,Ch.J.: 10 Steps to Best - Practices Benchmarking. www.qualitydigest.com (staženo 9.3.2010)

[8] CODLING,B.S. : Dynamics of best practice - a multidimensional perspective. Benchmarking: An International Journal, 1997, Vol. 4, No 2/1997, s. 96 - 103 . http://www.emeraldinsight.com/10.1108/14635779710174936 (ISSN: 1463-5771) (staženo 14.5.2010)

[9] STAPENHURST,T.: The Benchmarking Book: A How - to - Guide to Best Practice for Managers and Practitioners. Amsterdam. Elsevier. 2009, 454 s (ISBN 978-0-7506-8905-2) 